UDK 371.13:371.014.3

Originalni naučni rad

Primljeno: 26.8.2017.

Revidirana verzija: 30.11.2017.

Odobreno za štampu: 3.12.2017.

DOI: https://doi.org/10.46630/gped.1.2017.07

\title{
KOMPETENCIJE NASTAVNIKA ISTRAŽIVAČA REFLEKSIVNE NASTAVE
}

\author{
Jelena Osmanović ${ }^{1}$, Jelena Maksimović \\ Univerzitet u Nišu, Filozofski fakultet u Nišu, Departman za pedagogiju
}

\begin{abstract}
Apstrakt: Kompetencije koje karakterišu nastavnika refleksivnog praktičara su upravo one koje ga određuju za istraživača sopstvene prakse, kreatora sopstvenog razvoja, kao i kreatora kurikuluma šireg i užeg okruženja. Nastavnik refleksivni praktičar poseduje autonomnost u donošenju odluka. U radu se govori o nastavniku refleksivnom praktičaru, o refleksivnoj nastavi i o istraživanju nastavne prakse. Autorke su u radu ukazale na razliku između tradicionalnih nastavnika i modernih nastavnika refleksivnih istraživača sopstvene prakse koji umesto preuzimanja gotovih metodičkih postupka sa ciljem postizanja programskih ciljeva, aktivno osluškuju učenikove misli i osećanja, neprestano vrše opservaciju časa, traže nove izazove, reflektivni su, prave planove i postavljaju ciljeve, prihvataju razlike, prihvataju odgovornost za sebe i svoju okolinu, tolerantni su. Ono što karakteriše refleksivne praktičare istraživače jeste jedinstvena veza mišljenja i delovanja, epistemološka spirala saznanja i menjanja prakse, uvažavanje ne samo racionalnog nego i intuitivnog saznanja. S obzirom na to da obrazovanje obuhvata više nivoa, u istraživanju je akcenat stavljen na analizu izazova sa kojima se susreću nastavnici refleksivni praktičari istražujući nastavu, s obzirom na pol, s obzirom na tip škole u kojoj su zaposleni (osnovne i srednje škole) i različite godine radnog staža. Istraživanje je sprovedeno u školama na teritoriji grada Niša. Uzorak obuhvata 209 ispitanika. Podaci su pokazali da se vaspitno-obrazovni sistem, kao deo ukupnog sistema društva, mora stalno reformisati i usavršavati kako bi odgovorio svim zahtevima koji su mu postavljeni.
\end{abstract}

Ključne reči: istraživanje nastavne prakse, refleksivni praktičari, refleksivna praksa, stručno usavršavanje, modernizacija obrazovanja.

\section{Uvod}

Nije neistina ako kažemo da je profesija nastavnika izuzetno kompleksna i teška profesija i da zahteva dosta zalaganja, odricanja i posvećenosti nastavnika. Sa razvojem nauke i tehnologije, sa uvođenjem brojnih promena u obrazovno-vaspitni sistem, nastavnici su se našli pred brojnim izazovima od kojih ne smeju bežati, već

\footnotetext{
1 jelena.osmanovic@filozofski.rs
} 
sa kojima se moraju suočiti i uskladiti ih sa svojim sistemom vrednosti, stilom rada i ličnošću, ukoliko žele biti uspešni i primerni lideri u svom poslu. Interakcija i podučavanje učenika, kao i saradnja sa drugim članovima obrazovnog procesa, prepuna je stresnih situacija koje su u uskoj vezi sa elementima svakog obrazovnog sistema. Povećana odgovornost za učenike i njihov uspeh, učeničko nasilje, preveliki broj učenika u odeljenju, nedostatak prostora za održavanje nastave, slaba opremljenost škole savremenim nastavnim sredstvima, niska novčana nadoknada, visoki zahtevi profesije, uvođenje novih metoda rada, pritisci sa svih strana itd., samo su neki od razloga zbog kojih se nastavnik kao lider oseća ogorčenim i nesrećnim (Grujić, 2011). Iz ovoga proizlazi da nastavnici realizujući svoju ulogu često dolaze u konfliktne situacije koje od njih zahtevaju povećanu odgovornost i emocionalno naprezanje, što predstavlja veliki izazov kako u pogledu načina na koji će reagovati u tim situacijama, tako i u pogledu njihove emocionalne stabilnosti.

Nastavnik refleksivni praktičar alternativa je tradicionalnom praktičaru jer ima promenjen konceptualni i metodološki pristup praksi. On je aktivni pojedinac orijentisan na učenike, voljan da preispita vlastito mišljenje, da istraži mogućnosti i različite načine delovanja, kao odgovore na praktične probleme osluškujući učenikove misli i osećanja. U tom pogledu, nastavnik je aktivni kreator novih znanja o učenju, poučavanju i kurikulumu, a ne izvođač ekspertskih zamisli, proizvođač znanja struke. Razvoj praktičara implicira kompleksni, multidimenzionalni i dinamični sastav stvaranja i otkrivanja značenja, koji se razvija tokom celokupne profesionalne prakse, kao rezultat interakcije između osobe i njegove sredine (Coldron \& Smith, 1999). Nastavnik refleksivni praktičar jedna je od mogućih paradigmi njegovog doživotnog učenja i napredovanja. Ona je novi konceptualni i metodološki pristup koji se temelji na unapređivanju procesa učenja i poučavanja, te koji se javlja kao opozicija tehničkom i racionalnom (tradicionalnom) modelu razvoja praktičara (Maksimović, 2011).

\section{Refleksivni praktičar u funkciji istraživača vaspitno-obrazovne prakse}

Istraživanje Vlahović i Vujisić-Živković (2005) govori o nastavniku istraživaču, reflektivnom praktičaru, koji ima snage, koji bi trebalo i koji mora da vrši izmenu sopstvene prakse ispitivanjem ličnih kapaciteta, kao i kapaciteta škole, pri čemu individualno pronalazi najbolji put profesionalnog napredovanja i razvoja. Ukoliko osete potrebu da unaprede refleksivnu praksu potrebna je promena uloge nastavnika od pasivne realizatorske uloge ka aktivnoj istraživačkoj delatnosti u kojoj će preovladavati autonomnost nastavnika. Akcenat je tada na nastavnikovom profesionalnom razvoju i orijentisanju na pristup nastavi koja je zasnovana na refleksivnom i kritičkom promišljanju o praksi. Ako je cilj vaspitanja razvoj slobodne ličnosti, nastavnikova uloga i zadatak je da svojim ponašanjem obezbedi da učenici imaju slobodu izbora i da im omogući da aktiviraju i razvijaju sve aspekte svoje ličnosti do sopstvenog maksimuma (Baeher, 2013). 
Kompetencije koje karakterišu nastavnika refleksivnog praktičara su upravo one koje ga određuju kao istraživača sopstvene prakse, kreatora sopstvenog razvoja, kao i kreatora kurikuluma šireg i užeg okruženja. Kao što znamo, refleksivni praktičar drugačije razume i prilazi problemu i upravo to predstavlja kreativnu mogućnost za rešavanje pedagoških dilema na nov, inovativan način. Nastavnik refleksivni praktičar poseduje autonomnost u donošenju odluka, on je aktivni član i saradnik profesionalne grupe, ima dobro razvijen sistem vrednosti i modele ponašanja iz kojih kasnije proizlaze adekvatne odluke i dela. Umesto preuzimanja gotovih metodičkih postupka sa ciljem postizanja programskih ciljeva, nastavnik reflekivni praktičar aktivno osluškuje dečije misli i osećanja, vrši stalno opservaciju časa, traži nove izazove, pravi planove i postavlja ciljeve, prihvata razlike i odgovornost za sebe i svoju okolinu. Nastavnik refleksivni praktičar poseduje sledeće kompetencije: mora da poznaje karakteristike učenika, da podstiče učenike na rad, da ih ohrabruje, da je i sam aktivni slušalac, empatičnan, da teži celoživotnom usavršavanju, poseduje sposobnost za interdisciplinarno povezivanje sadržaja, daje dovoljnu slobodu u radu pojedinca, otvoren je za povratne informacije i stvaranje saradničke klime u odeljenju itd. (Radulović, 2007). Refleksivnog praktičara karakteriše jedinstvena veza mišljenja i delovanja, epistemološka spirala saznanja i menjanja prakse, uvažavanje ne samo racionalnog, nego i intuitivnog saznanja.

Da bismo saznali suštinu i obavezu refleksivnh praktičara objasnićemo razliku između istraživanja o obrazovanju koju realizuju naučnici i u kojima su nastavnici samo predmet istraživanja u obrazovanju koja realizuju praktičari. Karakteristika prvih je da su osmišljena nezavisno od potreba praktičara koji se istražuju i da se njima traga za opštim zakonitostima. Nasuprot njima su istraživanja koja imaju za cilj da unaprede i razviju konkretnu praksu praktičara koji istraživanje sprovodi (Vujisić-Živković, 2003). Nedostatak ovih prvih, Vlahović i Vujisić-Živković (2005) spoljnih, istraživanja je u tome što profesionalni istraživači istražuju problem u praksi koji oni sami odaberu, posmatraju ga van konkretnog, školskog konteksta i onda rezultate svog istraživanja objavljuju u naučnim radovima i časopisima. Tu se njihov rad završava. Oni ne prate dalje šta je sa tim njihovim rezultatima, da li ih nastavnici koriste kao rešenje problema $i$ ako ih koriste da li su pouzdani i efikasni. O važnosti refleksivne prakse, i onoga što se dešava u okviru učionice govore i neki od stranih autora (Chee Choy, 2011; Navaneedhan, 2001).

Brojne teškoće i izazovi sa kojima se nastavnici u svom radu susreću imaju kao rezultat negativne posledice koje se odražavaju ne samo na njih same, već i na učenike i njihovo postignuće u školi. U takvim okolnostima nastavnici pokazuju manje tolerancije i strpljenja za učenike i ostvaruju lošu interakciju sa njima. Povrh svega toga, u tim situacijama nastavnici su i manje kreativni i manje pozitivni i optimistični. Izazovi sa kojima se nastavnici susreću donekle se razlikuju u odnosu na to da li nastavnik radi sa učenicima osnovnoškolskog ili srednjoškolskog uzrasta. 


\section{Metodologija istraživanja}

Problem ovog istraživanja usmeren je na pitanje Da li kompetencije nastavnika refleksivnog praktičara koreliraju sa nezavisnim varijablama istraživanja?

Iz ovog problema proizlazi predmet istraživanja: Povezanost kompetentnosti nastavnika refleksivnog praktičara sa polom, godinama radnog staža i tipom ustanove u kojoj nastunici rade.

Cilj istraživanja je da ukažemo na izazove sa kojima se susreću refleksivni praktičari u toku svog radnog veka i istaknemo značaj razvijanja i negovanja kompetencija neophodnih u stručnim i profesionalnim usavršavanjim, kao i istraživanjima refleksivne prakse.

Zadaci postavljeni u ovom istraživanju su: 1. Ispitati povezanost kompetencija nastavnika za refleksivnu praksu sa polom, dužinom radnog staža i tipom obrazovne ustanove u kojoj rade (osnova i srednja škola); 2. Ispitati povezanost stavova nastavnika o promenama i novim oblicima rada refleksivnog praktičara sa polom, dužinom radnog staža i tipom obrazovne ustanove u kojoj rade (osnovna i srednja škola).

U istraživanju je korišćen survay istraživački metod, sa tehnikom skaliranja i instrumentom skale procene Likertovog tipa. U istraživanju je učestvovalo 209 nastavnika sa teritorije grada Niša.

Tabela 1. Stuktura ispitanika u odnosu na pol

\begin{tabular}{lccc}
\hline & & f & \% \\
\hline \multirow{3}{*}{ Pol ispitanika } & Muški & 94 & 45.0 \\
& Ženski & 115 & 55.0 \\
& Ukupno & 209 & 100.0 \\
\hline
\end{tabular}

Tabela 1 pokazuje da je u istraživanju učestvovalo ukupno $45 \%$ nastavnika i 55\% nastavnica, ukupno 209 ispitanika (100\% ukupnog uzorka).

Tabela 2. Struktura ispitanika u odnosu na godine radnog staža

\begin{tabular}{cccc}
\hline & & f & \% \\
\hline Dužina radnog staža & Do 10 godina & 65 & 31.1 \\
ispitanika & 11-20 godina & 83 & 39.7 \\
& Preko 20 godina & 61 & 29.2 \\
& Ukupno & 209 & 100.0 \\
\hline
\end{tabular}

Nastavnici koji su ušli u uzorak istraživanja bili su donekle ujednačeni po kriterijumu godina radnog staža. Najmlađih nastavnika s obzirom na radno iskustvo (do 10 godina) bilo je $31,1 \%$, zatim sa radnim iskustvom od 11 do 20 godina u nešto većem procentu $39,7 \%$, dok je sa najviše godina radnog iskustva (preko 20 godina) bilo ukupno $29,2 \%$ nastavnika. 
Tabela 3. Struktura isptanika u odnosu na na tip škole

\begin{tabular}{cccc}
\hline & & f & \% \\
\hline Varijabla & Osnovna skola & 114 & 54.5 \\
Osnovna i srednja škola & Srednja skola & 95 & 45.5 \\
& Ukupno & 209 & 100.0 \\
\hline
\end{tabular}

Struktura ispitanika s obzirom na tip škole u kojoj su ispitanici zaposleni prikazana je u tabeli 3. Zapravo od ukupnog broja ispitanih nastavnika 54,5\%, zaposleno je u osnovnim školama, dok 45,5 radi u srednjoškolskim ustanovama.

Dalji statistički podaci su prikazani statističkim postupkom Pirsonovog koeficijenta korelacije, tabelarnim putem.

\section{Analiza i interpretacija rezultata istraživanja}

Refleksivni pristup nastavniku predstavlja suštinski zaokret kako u praksi, obrazovanju nastavnika i istraživanju prakse. Refleksivni pristup sopstvenoj praksi, bila ona nastavnićka ili istraživačka, nužni je preduslov saznanja o tome šta zaista nastavnik radi, šta zna i u čemu bi trebalo da napreduje, kako na individualnom, tako i na društvenom planu. $U$ istraživanju smo postavili pitanje da li su refleksivni praktičari muškog ili ženskog pola ažurniji u istraživanju sopstvene refleksivne prakse? Da li veće angažovanje imamo kod ispitanika muškog ili ženskog pola? Da li su promenama podložniji i lakše ih prihvataju ispitanici muškog ili ženskog pola. Odgovori na postavljena pitanja prikazani su u tabeli 4.

Tabela 4. Korelacija kompetentnosti ispitanika za refleksivnu praksu i pola

\begin{tabular}{cccc}
\hline & & $\begin{array}{c}\text { Kompetentnost } \\
\text { nastavnika }\end{array}$ & Pol \\
\hline \multirow{3}{*}{ Kompetentnost ispitanika } & Pearson Correlation & 1 & -.019 \\
& Sig. (2-tailed) & & .789 \\
& $\mathrm{~N}$ & 209 & 209 \\
\multirow{2}{*}{ Pol } & Pearson Correlation & -.019 & 1 \\
& Sig. (2-tailed) & .789 & \\
& $\mathrm{~N}$ & 209 & 209 \\
\hline
\end{tabular}

Podaci pokazuju da kompetentnost ispitanika ne korelira sa polom. Kako bi ispitanici uspešnije realizovali ulogu refleksivnog praktičara, doprineli unapređivanju refleksivne prakse, neophodno je da poseduju kompetencije za čije sticanje je potrebno truda, rada i usavršavanja. S obzirom na važnost posedovanja kompetencija, u ovom radu akcenat je na ispitivanju stavova ispitanika o tome da li poseduju kompetencije za refleksivnu praksu. Dobili smo donekle očekivane rezultate, izgleda da ispitanici sebe smatraju izuzetno kompetentnim za istraživanje refleksivne prakse, što se može videti i u tabeli 4 ( $\mathrm{p}>0,05)$. 
Tabela 5. Korelacija kompetentnosti ispitanika za refleksivnu praksu i dužine radnog staža

\begin{tabular}{cccc}
\hline & & $\begin{array}{c}\text { Kompetentnost } \\
\text { nastavnika }\end{array}$ & $\begin{array}{c}\text { Duzina radnog } \\
\text { staza }\end{array}$ \\
\hline Kompetentnost ispitanika & Pearson Correlation & 1 & $-.297(* *)$ \\
& Sig. (2-tailed) & & .000 \\
Duzina radnog staža & $\mathrm{N}$ & 209 & 209 \\
& Pearson Correlation & $-.297(* *)$ & 1 \\
& Sig. (2-tailed) & .000 & \\
& $\mathrm{~N}$ & 209 & 209 \\
\hline
\end{tabular}

** Correlation is significant at the 0.01 level (2-tailed).

Podaci pokazuju da ispitanici zahvaljujući realizaciji odgovorne uloge stiču uvid u proces rada škole, na jedan potpuno drugačiji način, razvijajući nove kompetencije neophodne za refleksivnog praktičara, kao i istraživača refleksivne nastave. Te kompetencije obuhvataju: poznavanje epistemoloških obeležja refleksivne nastave, korišćenje rezultata drugih istraživača, poznavanje jezika, literature, pravila citiranja i pisanja bibliografskih i drugih naučnih izvora, poznavanje strukture pisanog naučnog izveštaja refleksivnog praktičara, poznavanje metoda prikupljanja podataka: posmatranje, intervjuisanje, anketiranje, skaliranje, analiza sadržaja, proučavanje slučaja, učešća u istraživačkim timovima i mnogo toga (Halmi, 2004; Maksimović, 2011; Matijević, 2004; Mužić, 2004; Mužić i sar., 2003; Pejović, 1983).

Istovremeno, uloga nastavniku pruža mogućnost da uspostavi snažne veze sa svojim učenicima i da inspiriše svoje kolege, roditelje, stručne saradnike. Na taj način nastavnici refleksivni praktičari doživljavaju kako ličnu, tako i profesionalnu satisfakciju, smanjuje se osećaj izolovanosti, a pri tome se stiču i nova iskustva i znanja koja su od značaja za nastavničku profesiju i dalji rad nastavnika. Na taj način možemo reći da stiču sve jače kompetencije važne za refleksivnu praksu. Istraživanje je pokazalo da postoji negativna korelacija sa dužinom radnog staža (Pearson Correlation=-0,30). Postoji statistički značajna povezanost kompetencija ispitanika sa godinama radnog staža $(\mathrm{p}<0,05)$. Ovaj podatak nam pokazuje da sa godinama radnog staža raste i kompetentnost nastavnika za refleksivnu praksu, odnosno što su manje godine radnog staža, kompetentnost nastavnika je manja.

Tabela 6. Korelacija kompetentnosti ispitanika za refleksivnu praksu i tipa obrazovne ustanove

\begin{tabular}{cccc}
\hline & Kompetentnost & $\begin{array}{c}\text { Tip obrazovne } \\
\text { ustanove }\end{array}$ \\
\hline Komptavnika & & -.071 \\
ispitanika & Pearson Correlation & 1 & .304 \\
& Sig. (2-tailed) & 209 & 209 \\
Tip obrazovne ustanove & $\mathrm{N}$ & -.071 & 1 \\
& Pearson Correlation & .304 & 209 \\
\hline
\end{tabular}


Tabela 6 pokazuje da nema statistički značajne povezanosti kompetentnosti ispitanika i tipa obrazovne ustanove $(\mathrm{p}>0,05)$. Bez obzira na to da li ispitanici rade u osnovnim ili srednjim školama osećaj kompetentnosti ispitanika je isti.

Tabela 7. Korelacija obrazovnih promena i pola

\begin{tabular}{cccc}
\hline & & Izazovi & Pol \\
\hline \multirow{3}{*}{ Izazovi } & Pearson Correlation & 1 & .087 \\
& Sig. (2-tailed) & & .209 \\
& $\mathrm{~N}$ & 209 & 209 \\
\multirow{2}{*}{ Pol } & Pearson Correlation & .087 & 1 \\
& Sig. (2-tailed) & .209 & \\
& $\mathrm{~N}$ & 209 & 209 \\
\hline
\end{tabular}

Profesija nastavnika izuzetno je kompleksna i teška profesija i samim tim zahteva dosta zalaganja, odricanja i posvećenosti nastavnika. Sa razvojem nauke i tehnologije, sa uvođenjem brojnih promena u obrazovno-vaspitni sistem, nastavnici su se našli pred brojnim izazovima od kojih ne smeju bežati, već sa kojima se moraju suočiti i uskladiti ih sa svojim sistemom vrednosti, stilom rada i ličnošću, ukoliko žele biti uspešni i primerni lideri u svom poslu. Podaci prikazani u tabeli 7 pokazuju da nema statistički značajne povezanosti izazova u obrazovnim promenama i pola. Bez obzira na to kog su pola, ispitanici se susreću sa istim izazovima podjednako.

Tabela 8. Korelacija obrazovnih promena i dužine radnog staža

\begin{tabular}{cccc}
\hline & & Izazovi & $\begin{array}{c}\text { Duzina radnog } \\
\text { staža }\end{array}$ \\
\hline \multirow{2}{*}{ Izazovi } & Pearson Correlation & 1 & -.009 \\
& Sig. (2-tailed) & & .895 \\
& $\mathrm{~N}$ & 209 & 209 \\
Dužina radnog staža & Pearson Correlation & -.009 & 1 \\
& Sig. (2-tailed) & .895 & \\
& $\mathrm{~N}$ & 209 & 209 \\
\hline
\end{tabular}

Tabela 8 potvrđuje ono što i prethodna tabela. Bez obzira na to da li imaju manje ili više godina radnog staža obrazovne promene i izazovi koje one nose sa sobom pogađaju kako starije tako i mlađe ispitanike ( $>>0,05)$. Kako se menja struktura u savremenoj školi, uvode inovacije, a koje posebno pogađaju nastavu i učenje, potrebno je da se menjaju i uloga i status nastavnika. Istraživanje je ovo i potvrdilo.

Tabela 9. Korelacija obrazovnih promena i tipa obrazovne ustanove

\begin{tabular}{cccc}
\hline & & Izazovi & $\begin{array}{c}\text { Tip obrazovne } \\
\text { ustanove }\end{array}$ \\
\hline \multirow{2}{*}{ Izazovi } & Pearson Correlation & 1 & .014 \\
& Sig. (2-tailed) & & .842 \\
& $\mathrm{~N}$ & 209 & 209
\end{tabular}




\begin{tabular}{cccc} 
& Pearson Correlation & .014 & 1 \\
Tip obrazovne ustanove & Sig. (2-tailed) & .842 & \\
& $\mathrm{~N}$ & 209 & 209 \\
\hline
\end{tabular}

Vaspitno-obrazovni sistem kao deo ukupnog sistema društva mora se stalno reformisati i usavršavati kako bi odgovorio svim zahtevima koji su mu postavljeni. To važi i za osnovnoškolsko i srednjoškolsko obrazovanje. Istraživanje je pokazalo da ne postoji statistički značajna povezanost obrazovnih promena i tipa obrazovne ustanove. Bez obzira na to da li nastavnici rade u osnovnim ili srednjim školama, svi se moraju prilagođavati promenama $u$ obrazovnom sistemu $(p>0,05)$.

\section{Zaključna razmatranja}

Svesni smo činjenice da je refleksivni pristup sopstvenoj praksi kakav danas poznajemo različit od nastave koja se nekada realizovala u školama. Naime, nekada se nastava odvijala isključivo putem frontalnog oblika rada, gde se od učenika očekivalo da pomno prate nastavnikovo izlaganje i usvajaju što veću količinu informacija koje im nastavnik pruža u gotovom obliku, kako bi ih kasnije mehanički reprodukovali. Jednom rečju, naglasak je bio na kvantitetu, ali ne i na kvalitetu. Iz ovih razloga je važno da ukažemo zašto je promenjena uloga nastavnika i to je razlog da današnji nastavnici postanu refleksivni praktičari i istraživači refleksivne nastave. Istraživanje je pokazalo da su hipoteze istraživanja potvrđene i da ne postoje statistički značajne korelacije između kompetencija nastavnika refleksivnih praktičara i izazova sa kojima se susreću sa polom nastavnika, godinama radnog staža nastavnika i tipa ustanove u kojima su zaposleni. Istraživanje je pokazalo da su mlađi nastavnici po godinama radnog staža manje kompetentni od stariji kolega. Sa godinama radnog staža raste i njihovo iskustvo i postaju bolji refleksivni praktičari.

Refleksivni pristup nastavniku predstavlja suštinski zaokret kako u praksi, obrazovanju nastavnika i istraživanju prakse. Na temelju prethodno izloženih stavova jasno možemo uvideti da refleksivni nastavnik neprestano mora usavršavati sopstvene kompetencije, zatim da aktivno osluškuje refleksivnu nastavu, posmatra aktivnosti, uočava njihove mogućnosti i nastoji da pronađe adekvatne postupke kojim će tu praksu istraživati i unapređivati je. Pri tome (...) dopušta iznenađenja različitim nepredvidivim situacijama u kojima mu njegova prethodna iskustva i znanja ne mogu poslužiti kao adekvatan odgovor, već mu u tome pomaže njegovo profesionalno umeće (Schön, 1987; 1990). 


\section{Literatura}

Baeher, J. (2013). Educating for Intellectual Vitues: From Theory to Practice. Journal of Philosophy od Education, 47(2), 248-262.

Chee Choi, S. (2011). Reflektive thinking and teaching practice: a Precusor for incorporating critical thinking into the classroom? International Journal of Instruction, Vol.5, No.1

Coldron, J. \& Smith, R. (1999). Active location in teachers' construction of their professional identities. Journal of Curriculum Studies, 31(6), 711-726.

Grujić, Lj. (2011). Profesionalno sagorevanje nastavnika, Pedagogija, 66(2), 215-223.

Halmi, A. (2004). Strategije kvalitativnih istraživanja u primijenjenim društvenim znanostima. Jastrebarsko: Naklada Slap.

Maksimović, J. (2011). Akciona istraživanja i refleksivnost nastavnika. Godišnjak SAO za 2010. godinu, Srpska akademija obrazovanja, Beograd, 803-816.

Matijević, M. (2004). Metodološka pitanja didaktike, U: L. Bognar i M. Matijević. Didaktika. Zagreb: Školska knjiga.

Mužić, V. (2004). Uvod u metodologiju istraživanja odgoja i obrazovanja. Zagreb: EDUCA.

Mužić, V., Matijević, M. i Jokić, M. (2003). Istraživati i objaviti: elementi metodološke pismenosti. Zagreb: Hrvatski pedagoško-književni zbor.

Navaneedhan, G. (2001). Reflective teaching pedagogiy as innovative approach in teacher education trough open and distance learnin. Journal of Media and Communication Studies, 3(12), 331-335.

Schön, D. (1987). Education the reflective practitioner. San Francisko: Oxford.

Schön, D. (1990). Educating the Reflective Practitioner: Toward a New Design for Teaching and Learning in the Professions. San Francisco/Oxford: Jossey-Bass Publishers

Pejović, D. (1983). Hermeneutika, znanost i praktična filozofija. Sarajevo: Veselin Masleša

Radulović, L. (2007). Istraživanje i razvijanje obrazovanja nastavnika za refleksivnu praksu - kritički prikaz jednog istraživanja kao gradjenje obrazovnog programa. Pedagogija (LXII) 4, 136-151.

Vlahović, B. i Vujisić Živković, N. (2005). Učitelj-izazovi profesionalizacije. Beograd: Forum pedagoga Srbije i Crne Gore.

Vujisić-Živković, N. (2003). Istraživanje u profesionalnom obrazovanju učitelja. Pedagogija, (41) 3-4, 130-139. 


\title{
TEACHERS' COMPETENCIES OF REFLECTIVE TEACHING
}

\author{
Jelena Osmanović, Jelena Maksimović \\ University of Niš, Faculty of Philosophy, Niš, Department of Pedagogy
}

\begin{abstract}
The competences characterized by reflexive practitioners are precisely the ones they designate for the researcher of their own practice, the creators of their own development, as well as the creators of the curriculum of a wider and narrower environment. The teacher's reflexive practitioner has autonomy in making decisions. This paper discusses the teacher with a reflexive practitioner, about reflexive teaching, and about teaching teaching practice. The authors pointed out the difference between traditional teachers and modern teachers of reflexive researchers of their own practice who, instead of taking ready methodical procedures with the aim of achieving program goals, actively listening to the student's thoughts and feelings, constantly observing the time, looking for new challenges, reflective, real plans, and set goals, accept differences, accept responsibility for themselves and their environment, are tolerant. What reflects researchers' reflexive practitioners is a unique link of thought and action, the epistemological spiral of knowing and changing practices, respecting not only rational but also intuitive knowledge. Given that education involves multiple levels, the emphasis in the research is on analyzing the challenges faced by teachers reflexive practitioners by studying teaching, with regard to gender, given the type of school in which employees (primary and secondary schools) and various years of service. The research was conducted in schools in the territory of the city of Niš. The sample includes 209 respondents. The data showed that the educational system, as part of the overall system of society, must constantly be reformed and improved in order to meet all the requirements set for it.
\end{abstract}

Key Words: teaching practice research, reflexive practitioners, reflexive practice, professional development, modernization of education.

\section{Citiranje članka:}

Osmanović, J. i Maksimović, J. (2017). Kompetencije nastavnika istraživača refleksivne nastave. Godišnjak za pedagogiju, 2(1), 79-88. 